\title{
A Newly Developed Real-Time PCR Assay for Detection and Quantification of Fusarium oxysporum and Its Use in Compatible and Incompatible Interactions with Grafted Melon Genotypes
}

\author{
Anita Haegi, Valentina Catalano, Laura Luongo, Salvatore Vitale, Michele Scotton, \\ Nadia Ficcadenti, and Alessandra Belisario
}

\begin{abstract}
First, second, third, fourth, and seventh authors: Consiglio per la ricerca e la sperimentazione in agricoltura (CRA)-Centro di Ricerca per la Patologia Vegetale, Via C. G. Bertero 22, 00156 Rome; fifth author: Department of Agronomy Foods Natural Resources Animals and Environment, University of Padova, Viale dell'Università 16, 35020 Legnaro, Padova, Italy; and sixth author: CRA-Unità di Ricerca per l'Orticoltura Via Salaria 1, 63077 Monsampolo del Tronto (AP), Italy.
\end{abstract}

Accepted for publication 27 February 2013.

\begin{abstract}
Haegi, A., Catalano, V., Luongo, L., Vitale, S., Scotton, M., Ficcadenti, N., and Belisario, A. 2013. A newly developed real-time PCR assay for detection and quantification of Fusarium oxysporum and its use in compatible and incompatible interactions with grafted melon genotypes. Phytopathology 103:802-810.

A reliable and species-specific real-time quantitative polymerase chain reaction (qPCR) assay was developed for detection of the complex soilborne anamorphic fungus Fusarium oxysporum. The new primer pair, designed on the translation elongation factor $1-\alpha$ gene with an amplicon of $142 \mathrm{bp}$, was highly specific to $F$. oxysporum without cross reactions with other Fusarium spp. The protocol was applied to grafted melon plants for the detection and quantification of F. oxysporum f. sp. melonis, a devastating pathogen of this cucurbit. Grafting technologies are widely used in melon to confer resistance against new virulent races of $F$. oxy-

'Charentais-T' (susceptible) and 'Nad-1' (resistant) melon cultivars, both used either as rootstock and scion, and inoculated with $F$. oxysporum f. sp. melonis race 1 and race 1,2. Pathogen development was compared using qPCR and isolations from stem tissues. Early asymptomatic melon infections were detected with a quantification limit of $1 \mathrm{pg}$ of fungal DNA. The qPCR protocol clearly showed that fungal development was highly affected by host-pathogen interaction (compatible or incompatible) and time (days postinoculation). The principal significant effect ( $P \leq$ 0.01 ) on fungal development was due to the melon genotype used as rootstock, and this effect had a significant interaction with time and F. oxysporum f. sp. melonis race. In particular, the amount of race 1,2 DNA was significantly higher compared with that estimated for race 1 in the incompatible interaction at 18 days postinoculation. The two fungal races were always present in both the rootstock and scion of grafted plants in either the compatible or incompatible interaction.
\end{abstract} sporum f. sp. melonis, while maintaining the properties of valuable commercial varieties. However, the effects on the vascular pathogen colonization have not been fully investigated. Analyses were performed on
Additional keywords: Cucumis melo, Fusarium wilt, SYBR green.
Fusarium oxysporum Schltdl. is a fungal soilborne facultative parasite present worldwide. The species includes nonpathogenic and pathogenic strains, the latter causing vascular wilt and root rot on many economically important crops. The identification of pathogenic F. oxysporum isolates is traditionally based on pathogenicity testing, which is time consuming and laborious. Pathogenic $F$. oxysporum strains have been subdivided into over 100 different host-specific forms (formae speciales) which are morphologically indistinguishable and represent intraspecific groups of strains with similar or identical host ranges $(6,21,27)$. A forma specialis can be further subdivided into races on the basis of characteristic virulence patterns on differential host cultivars (14). F. oxysporum f. sp. melonis W. C. Snyder \& H. N. Hansen is specific to melon (Cucumis melo L.). Four races of the pathogen (races $0,1,2$, and 1,2) have been defined according to host resistance genes overcome by variants of the pathogen (33).

Once introduced into the field, F. oxysporum f. sp. melonis can persist in soil over extended periods on crop residues and nonhost crops, and by forming chlamydospores (15). Although many Fusarium spp. can penetrate into the cortical tissue of roots, only

Corresponding author: A. Belisario; E-mail address: alessandra.belisario@entecra.it

http://dx.doi.org/10.1094/PHYTO-11-12-0293-R

(c) 2013 The American Phytopathological Society host-specific strains can penetrate the vascular elements by mycelial growth and form microconidia transported in the sap stream $(6,25)$. Therefore, effective control can be achieved only through host resistance. Two dominant, independently-inherited resistance $(R)$ genes (Fom-1 and Fom-2) provide resistance to races 0 and 2, and races 0 and 1 , respectively (33). Resistance to race 1,2 is complex and appears to be controlled by multiple recessive genes. Partial resistance was introgressed into 'Isabelle' melon (30), from which two doubled-haploid (DH) resistant lines, 'Nad-1' and 'Nad-2' were derived, which are resistant to $F$. oxysporum $\mathrm{f}$. sp. melonis race 1 and race 1,2 (10). At present, only partially resistant genotypes are commercially available, mainly as rootstocks, to protect against race 1,2 damage. Grafting represents an effective tool for controlling $F$. oxysporum f. sp. melonis races (3), particularly applied against race 1,2, the most widespread and harmful $F$. oxysporum f. sp. melonis race $(10,37)$. Research in grafting of melon started in the late 1920s (34). The main purpose was to reduce the damage of Fusarium wilt using resistant rootstocks. Successively, Fom-1 and Fom-2 resistant genes were extensively incorporated into melon cultivars, reducing the need to use grafting technologies in melon for some time. When $F$. oxysporum f. sp. melonis race 1,2 became widespread, melon rootstock cultivars with multiple disease resistances were developed and used extensively to avoid Fusarium wilt damage (34). Symptoms do not occur on susceptible scions when grafted on a resis- 
tant rootstock. Nevertheless, F. oxysporum f. sp. melonis is reported to be present inside the host in either the compatible or incompatible interaction, and has been reisolated from the stem of resistant melon genotypes $(3,37,40)$.

Isolations from infected plants are commonly used to verify the presence of pathogens in the host at any given time point of pathogenesis. Further information on the pathogen spreading inside the host has been reported in literature with the employment of green fluorescent protein (GFP) as a marker, which clearly documented the progress of the infection for xylemcolonizing $F$. oxysporum strains $(6,16,40)$, but failed to quantify the amount of fungal biomass in host tissues. During the last decade, new DNA-based technology, such as the polymerase chain reaction (PCR) assay, has been developed to support morphology-based identifications of phytopathogenic fungi. Two specific PCR assays have been developed for the detection of $F$. oxysporum, but none of them were quantitative in nature $(8,26)$. Today, quantitative real-time PCR (qPCR) has become the most reliable methodology for detection and quantification of a variety of plant pathogens $(7,19,36)$. In this context, the species-specific PCR primers developed by Mishra et al. (26) on the internal transcribed spacer ribosomal DNA region were successively adapted to qPCR and tested for their specificity against several Fusarium spp. or $F$. oxysporum formae speciales, including one isolate of $F$. oxysporum f. sp. melonis (18). Recently, a sequencecharacterized amplified region (SCAR)-based real-time TaqMan PCR has been developed for F. oxysporum (23) and applied to F. oxysporum f. sp. melonis. Nevertheless, the specificity of this method was tested on few fungal strains, which do not represent the broad variability of the $F$. oxysporum species complex.

Different DNA regions have been used to design real-time PCR primers for identification of fungi. In particular, translation elongation factor $\alpha$ (TEF-1 $\alpha)$ is extensively used in Fusarium phylogeny, because it is highly informative at the species level, nonorthologous copies of the gene have not been detected in the genus, and universal primers have been designed $(13,22)$. In this study, we report on a species-specific DNA primer pair developed on TEF- $1 \alpha$. The newly developed protocol was used to detect and assess fungal DNA amount in grafted melon plants infected by F. oxysporum f. sp. melonis race 1 or race 1,2 , in either compatible or incompatible interactions. Tissue stem fragments were taken at different heights and times in both the rootstock and the scion and used for either fungal reisolations or fungal biomass detection and quantification by qPCR.

The objectives of this research were to develop a speciesspecific and sensitive detection method for $F$. oxysporum to apply in melon plants, with the aim of quantifying $F$. oxysporum $\mathrm{f}$. sp. melonis DNA within compatible and incompatible interactions in either grafted or ungrafted plants, and to understand the impact of grafting on the development of $F$. oxysporum $\mathrm{f}$. sp. melonis inside the host.

\section{MATERIALS AND METHODS}

Host material. Two melon genotypes 'Charentais-T' (CHT-T), fully susceptible, and $\mathrm{Nad}-1$, resistant to $F$. oxysporum f. sp. melonis race 1 and race 1,2, were grafted (3) in both reciprocal combinations and inoculated either with $F$. oxysporum f. sp. melonis race 1 (strain ISPaVe1070) or F. oxysporum f. sp. melonis race 1,2 (strain ISPaVe1018) obtained from a single spore culture. Inoculation was carried on at the four- to five-true-leaf stage by dipping the plant roots in a suspension of $1 \times 10^{6}$ conidia $/ \mathrm{ml}$ for $30 \mathrm{~min}$, according to Sestili et al. (37). Plants were kept in greenhouse under controlled conditions $(10,37)$.

In preliminary experiments, grafted and ungrafted melon plants were analyzed for $F$. oxysporum f. sp. melonis reisolations at 2, 4, 14, and 18 days postinoculation (dpi), and 2 and 18 dpi were the most significant time points in stressing differences between the two F. oxysporum f. sp. melonis races, as reported by Sestili et al. (37). Hence, only 2 and 18 dpi were further considered for either reisolations or qPCR analyses. At $18 \mathrm{dpi}$, all plants undergoing the compatible interaction displayed obvious wilting symptoms. Hence, melon plants grafted in both combinations were inoculated with either race 1 or race 1,2 and collected at 2 and 18 dpi. Water-inoculated grafted and ungrafted plants were used as controls. Three replicate plants (biological replicates) for each treatment (melon-genotype grafting combination $\times F$. oxysporum f. sp. melonis race or water) and collection time were used for reisolation assays or for qPCR analysis, while inoculated ungrafted plants of the same genotypes were used for comparison in qPCR only. All inoculations were repeated three times. A completely randomized distribution was adopted for the melon plants kept in the greenhouse under controlled conditions at $25 \pm 2^{\circ} \mathrm{C}$ with 80 to $90 \%$ relative humidity and a 16 -h photoperiod $(10,37)$.

Analyses were performed on melon stems which were prepared by removing roots and discarding the basal $15 \mathrm{~mm}$. Successively, they were abundantly washed under running tap water, surface disinfested in $1 \% \mathrm{NaOCl}$ for $30 \mathrm{~s}$ followed by $2 \times 30 \mathrm{~s}$ in sterile deionized water, and dried on sterile filter paper sheets in a laminar flow hood. The whole stem length considered was $\approx 70 \mathrm{~mm}$ and sections were excised from top to bottom (37).

Reisolations were performed only on grafted melon plants (CHT-T scion/Nad-1 rootstock and Nad-1/CHT-T). Stems were cut in six sections above and six below the grafting point for a total of 12 stem segments $(\approx 5 \mathrm{~mm}$ long) per plant. Sections were placed in petri dishes onto potato dextrose agar (PDA; Oxoid, Basingstoke, UK) in an ordered manner (37). A completely randomized distribution was adopted for petri dishes incubated at room temperature for $\approx 7$ days and examined for the appearance of fungal outgrowths.

For the qPCR assay tissue, two fragments above 45 to $70 \mathrm{~mm}$ and two below 15 to $40 \mathrm{~mm}$ of the stem length were excised in grafted and ungrafted melon plants. For ungrafted plants of Nad-1, only the late time point (18 dpi) was considered because the number of plants available was not sufficient to include the 2-dpi analysis.

DNA extraction. For DNA extraction, both grafted (CHTT/Nad-1 and Nad-1/CHT-T) and ungrafted (Nad-1 and CHT-T) melon plants were considered. Stem sections were ground to a fine powder under liquid nitrogen with a sterile mortar and pestle. DNA was extracted and purified according to the protocol of Wizard genomic DNA purification kit (Promega Corp., Madison, WI). The concentration of DNA was measured spectrophotometrically (Nanodrop ND-1000; Thermo Fisher Scientific Inc., Waltham, MA). Special care was taken to obtain accurate concentrations of total DNA by quantifying each DNA sample in triplicate in two independent microplates. As an internal control of DNA quantification, a DNA sample of known concentration was included in each quantification plate.

Primer design and qPCR assay. A primer pair specific to $F$. oxysporum was designed by comparison of TEF- $1 \alpha$ gene sequences generated by EF1/EF2 primer pair amplification (28) of Fusarium spp. listed in Table 1. Additional sequences of Fusarium spp. were retrieved from GenBank and used for an in silico comparative analysis (Table 2). Sequences were aligned using CLUSTALX (38). Specific primers were designed by the program PRIMER3 (http://primer3.sourceforge.net/). Primer selection was based on a minimum formation of secondary structure and an amplicon size of 100 to $200 \mathrm{bp}$.

The specificity of the newly designed primer pair was tested in conventional PCR against DNA extracted from the fungal isolates listed in Table 1. All reactions always included positive ( $F$. oxysporum f. sp. melonis DNA, isolate ISPaVe1018 or ISPaVe1070) and negative controls and were analyzed by gel electrophoresis to confirm that only one PCR product was present and no amplification product was obtained from negative controls. 
To optimize the qPCR reaction conditions, annealing temperature, $\mathrm{MgCl}_{2}$, and primer concentrations were adjusted experimentally. qPCR was carried out in the CFX96 Real-Time PCR Detection System (Bio-Rad, Hercules, CA) on the three biological replicates of each treatment, with three technical replicates each. A Fusarium-free melon plant DNA sample was used as negative control. A dissociation curve was included at the end of the qPCR program to evaluate potential primer-dimers and nonspecific amplification products. DNA standard curves for qPCR assays were obtained from 10-fold dilutions of F. oxysporum f. sp.

TABLE 1. List of fungal strains used in this study

\begin{tabular}{|c|c|c|c|}
\hline Isolate & Host & Race & Origin \\
\hline Fusarium oxysporum f. sp. melonis ISPaVe673 & Melon & 0 & Italy \\
\hline F. oxysporum f. sp. melonis ISPaVe 289 & Melon & 0 & Italy \\
\hline F. oxysporum f. sp. melonis ISPaVe676 & Melon & 0 & Italy \\
\hline F. oxysporum f. sp. melonis ISPaVe1069 & Melon & 1 & Italy \\
\hline F. oxysporum f. sp. melonis ISPaVe 1070 & Melon & 1 & Italy \\
\hline F. oxysporum f. sp. melonis ISPaVe 1074 & Melon & 1 & Italy \\
\hline F. oxysporum f. sp. melonis ISPaVe 1077 & Melon & 1 & Italy \\
\hline F. oxysporum f. sp. melonis ISPaVe1085 & Melon & 1 & Italy \\
\hline F. oxysporum f. sp. melonis ISPaVe1297 & Melon & 1 & Italy \\
\hline F. oxysporum f. sp. melonis ISPaVe1404 ${ }^{\mathrm{a}}$ & Melon & 1 & United States \\
\hline F. oxysporum f. sp. melonis ISPaVe1018 & Melon & 1,2 & Italy \\
\hline F. oxysporum f. sp. melonis ISPaVe 1083 & Melon & 1,2 & Italy \\
\hline F. oxysporum f. sp. melonis ISPaVe 1680 & Melon & 1,2 & Italy \\
\hline F. oxysporum f. sp. melonis ISPaVe1681 & Melon & 1,2 & Italy \\
\hline F. oxysporum f. sp. melonis ISPaVe1684 & Melon & 1,2 & Italy \\
\hline F. oxysporum f. sp. melonis ISPaVe1689 & Melon & 1,2 & Italy \\
\hline F. oxysporum f. sp. melonis ISPaVe1692 & Melon & 1,2 & Italy \\
\hline F. oxysporum f. sp. melonis ISPaVe 1693 & Melon & 1,2 & Italy \\
\hline F. oxysporum f. sp. melonis ISPaVe1694 & Melon & 1,2 & Italy \\
\hline F. oxysporum f. sp. melonis ISPaVe1697 & Melon & 1,2 & Italy \\
\hline F. oxysporum f. sp. melonis ISPaVe 1698 & Melon & 1,2 & Italy \\
\hline F. oxysporum f. sp. melonis ISPaVe 1700 & Melon & 1,2 & Italy \\
\hline F. oxysporum f. sp. melonis ISPaVe1406 ${ }^{\mathrm{a}}$ & Melon & 2 & United States \\
\hline F. oxysporum f. sp. melonis ISPaVe1408 ${ }^{\mathrm{a}}$ & Melon & 2 & United States \\
\hline F. oxysporum f. sp. melonis $\mathrm{ISPaVe} 2068^{\mathrm{b}}$ & Melon & 2 & Israel \\
\hline F. oxysporum f. sp. melonis ISPaVe $2069^{\mathrm{b}}$ & Melon & 2 & Israel \\
\hline F. oxysporum f. sp. basilici $\mathrm{ISPaVe} 2097^{\mathrm{c}}$ & Basil & - & Switzerland \\
\hline F. oxysporum f. sp. cucumerinum ISPaVe $2098^{\mathrm{d}}$ & Watermelon & - & Greece \\
\hline F. oxysporum f. sp. radicis-cucumerinum $\mathrm{ISPaVe} 2100^{\mathrm{d}}$ & Watermelon & - & Greece \\
\hline F. oxysporum f. sp. lycopersici ISPaVe 2102 & Tomato & - & Italy \\
\hline F. oxysporum f. sp. radicis-lycopersici ER $1553^{\mathrm{e}}$ & Tomato & - & Italy \\
\hline F. crookwellense ISPaVe1831 & Wheat & - & Italy \\
\hline F. crookwellense ISPaVe1857 & Potato & - & Italy \\
\hline F. culmorum ISPaVe1522 & Durum wheat & - & Italy \\
\hline F. culmorum ISPaVe1559 & Durum wheat & - & Italy \\
\hline F. equiseti ISPaVe1754 & Durum wheat & - & Italy \\
\hline F. equiseti $\mathrm{ISPaVe} 1811$ & Durum wheat & - & Italy \\
\hline F. lateritium ISPaVe1960 & Walnut & - & Italy \\
\hline F. lateritium ISPaVe2002 & Hazelnut & - & Italy \\
\hline F. oxysporum ISPaVe18 & Artichoke & - & Italy \\
\hline F. oxysporum $\mathrm{ISPaVe} 904$ & Watermelon & - & Italy \\
\hline F. poae ISPaVe1704 & Durum wheat & - & Italy \\
\hline F. proliferatum ISPaVe1110 & Sorghum & - & Italy \\
\hline F. proliferatum ISPaVe921 & Melon & - & Italy \\
\hline F. redolens ER $1276^{\mathrm{f}}$ & Lentil & - & Italy \\
\hline F. redolens $\mathrm{ER} 1277^{\mathrm{f}}$ & Lentil & - & Algeria \\
\hline F. semitectum ISPaVe1946 & Walnut & - & Italy \\
\hline F. semitectum ISPaVe2096 & Walnut & - & Italy \\
\hline F. solani $\mathrm{ISPaVe} 2057$ & Gardenia & - & Italy \\
\hline F. solani ISPaVe1962 & Walnut & - & Italy \\
\hline F. solani f. sp. cucurbitae ISPaVe931 & Zucchini & 1 & Italy \\
\hline Plectosporium tabacinum ISPaVe835 & Zucchini & - & Italy \\
\hline Monosporascus cannonballus ER $1327^{\mathrm{e}}$ & Melon & - & Italy \\
\hline M. cannonballus ER1328e & Melon & - & Italy \\
\hline M. cannonballus ER1329e & Melon & - & Italy \\
\hline Acremonium cucurbitacearum ER1179e & Melon & - & Italy \\
\hline A. cucurbitacearum ER1516 & Watermelon & - & Italy \\
\hline A. cucurbitacearum ER1517 e & Melon & - & Italy \\
\hline Rhizopycnis vagum $\mathrm{ER} 925^{\mathrm{e}}$ & Tomato & - & Italy \\
\hline Pyrenochaeta lycopersici ER1320 & Tomato & - & Spain \\
\hline P. lycopersici ER $1278^{\mathrm{e}}$ & Tomato & - & Italy \\
\hline P. lycopersici ER876 & Tomato & - & Italy \\
\hline
\end{tabular}

a Strains supplied by T. R. Gordon, Department of Plant Pathology, University of California, Davis.

b Strains supplied by R. Perl-Treves, The Mina \& Everard Goodman Faculty of Life Sciences, Bar-llan University, Ramat-Gan, Israel.

c Strain supplied by G. Tamietti, Università di Torino, DIVAPRA, Torino, Italy.

d Strain supplied by D. J. Vakalounakis, National Agricultural Research Foundation, Plant Protection Institute, Heraklion, Greece.

e Strain supplied by A. Infantino, CRA-Centre of Plant Pathology Research, Rome.

f Strain supplied by L. Riccioni, CRA-Centre of Plant Pathology Research, Rome. 
melonis isolate ISPaVE1018 or ISPaVE1070. For this purpose, fungal DNA $(10 \mathrm{ng} / \mu \mathrm{l})$ was serially diluted $\left(1: 1,1: 10,1: 10^{2}\right.$, $1: 10^{3}$, and $1: 10^{4}$ ) in sterile ultrapure water as well as in a fixed background of plant DNA (50 ng) extracted from stem. Standard curves were generated by plotting logarithmic values of known quantities of target DNA versus the corresponding cycle threshold $(\mathrm{Ct})$ values. After optimization, fungal DNA amount was assessed in both grafted melon plants and ungrafted genotypes for comparative purposes.

Statistical analysis. The isolation assay was a factorial experiment with three factors (time, melon genotype combination, and fungal race) and three replicates (plants). The section height on the stem cannot be considered as a further factor in an analysis of variance (ANOVA) design, because the sections were excised from the same plant (nonindependence of error). The presence or absence values obtained for the six sections excised above or the six sections excised below the grafting point were pooled into two percentage values of $F$. oxysporum $\mathrm{f}$. sp. melonis presence calculated for each plant. Both sets of values, obtained either below or above the grafting point, were separately subjected to ANOVA. Because the two sets did not match the parametric ANOVA requirements with any transformation, the nonparametric approach of the Monte Carlo permutation test was used. To generate probabilities for the main effects, permutations were restricted within the levels of the other factor (9). Interactions were tested by unrestricted permutations after the calculation of residuals (1). Statistical tests used for main factors and interactions were the sum of squares between groups $(\mathrm{Qb})$ and the pseudo $\mathrm{F}$ ratio $(\mathrm{F}=$ $\mathrm{Qb} / \mathrm{Qw}$, where $\mathrm{Qw}$ is the sum of squares within groups), respectively. In both ANOVAs, a significant interaction of melon genotype combination $\times$ time was detected; therefore, the effects of time and melon genotype combination were tested separately for each level of the other factor. Analyses were performed using Multiv software (31).

Data obtained by qPCR, calculated as pathogen DNA amount in $1 \mathrm{ng}$ of plant DNA, were averaged for the two lower stem part sections $(15$ to $40 \mathrm{~mm}$ ), and the same procedure was applied to data obtained from the two higher stem sections (45 to $70 \mathrm{~mm}$ ).
The two data sets were further processed separately. To meet the parametric tests assumptions, data of each set were rank-transformed according to Conover and Iman (4) and analyzed through parametric ANOVA performed with SAS (35). Because the factorial design was not complete due to the lack of 2-dpi data for Nad-1 ungrafted plants, each data set was subjected to two factorial ANOVAs, with the first (AV1) considering two fungal races, four melon genotype combinations, and only one time (18 dpi) and the second (AV2) considering two fungal races, two times ( 2 and $18 \mathrm{dpi}$ ), and only three melon genotype combinations (the Nad-1 ungrafted plant data set was excluded). Standard regression lines obtained from fungal DNA diluted with either water or melon DNA were statistically compared for homogeneity $(P \geq 0.05)$ of variance (Bartlett's test) and for equality of slopes and intercepts using an $F$ test at $P<0.05$. Tukey's multiple range test $(P \leq 0.01)$ was performed on means of pathogen DNA amounts estimated either below or above the grafting point or in ungrafted melon plants.

\section{RESULTS}

Presence of $F$. oxysporum f. sp. melonis race 1 or 1,2 by isolations from infected grafted melon plants. Results of the isolation analysis for presence or absence of $F$. oxysporum f. sp. melonis along the stem during compatible and incompatible interaction with melon grafted plants are shown in Figure 1. The reaction of the whole grafted plant was conditioned by the genotype used as rootstock. In the compatible interaction, there were no significant differences between the two races for the colonization pattern (Fig. 1). In fact, Nad-1/CHT-T grafted plants (compatible interaction) were totally colonized at $18 \mathrm{dpi}$ by both F. oxysporum f. sp. melonis races (Fig. 1) and all plants were symptomatic. Grafted CHT-T/Nad-1 plants (incompatible interaction) responded to infection by both $F$. oxysporum $\mathrm{f}$. sp. melonis races by remaining symptomless, as if the whole plant were a resistant genotype (i.e., Nad-1). Nevertheless, isolations were positive and a different colonization profile was evident between $F$. oxysporum f. sp. melonis race 1 (ISPaVe1070) and race 1,2 (ISPaVe1018), especially concerning the time needed for colonizing the scion
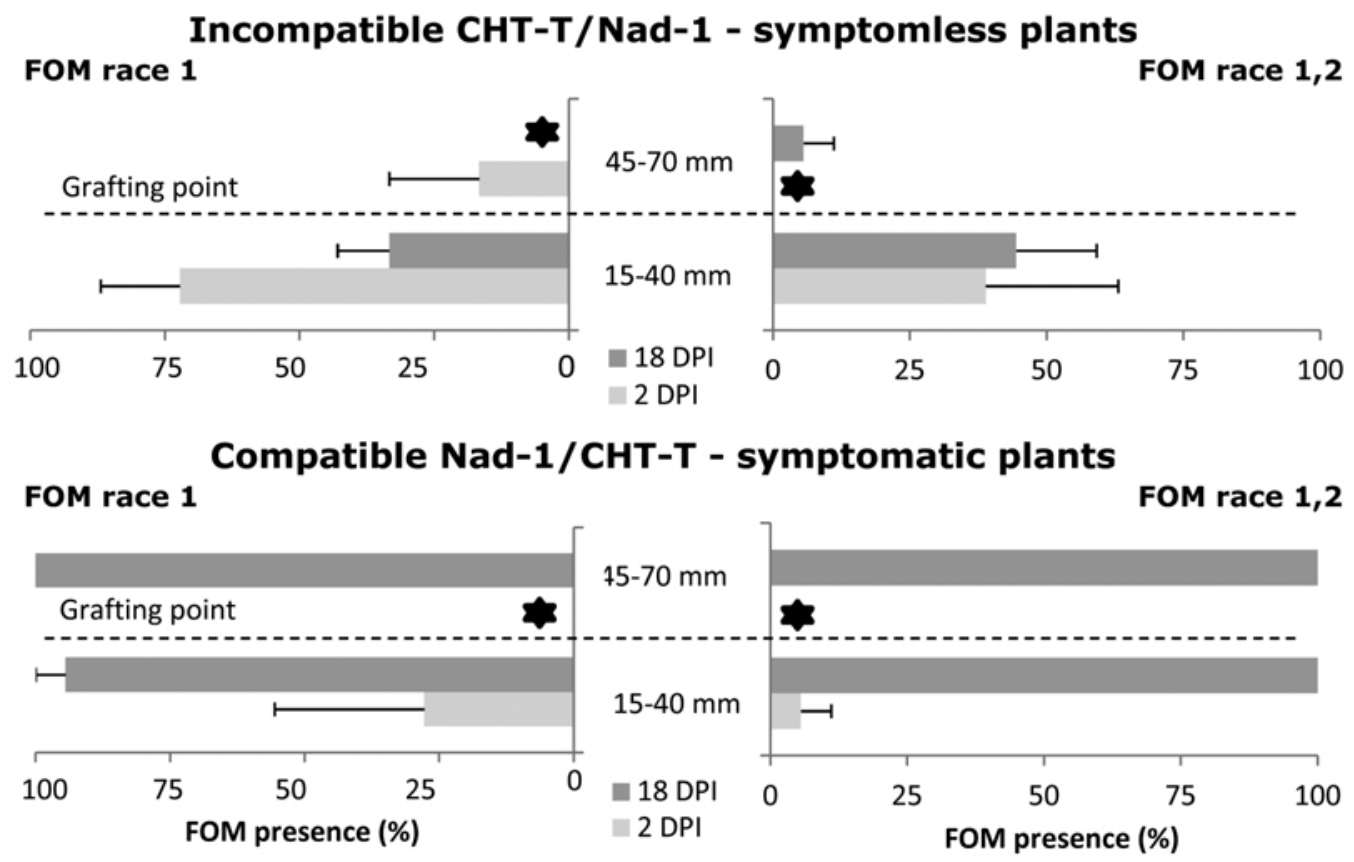

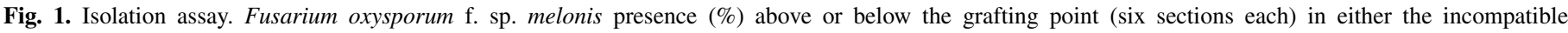

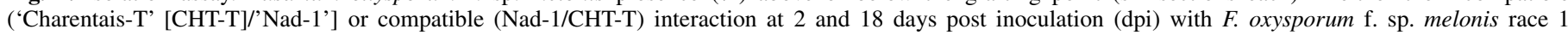

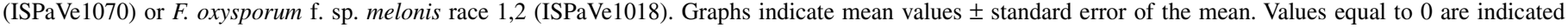

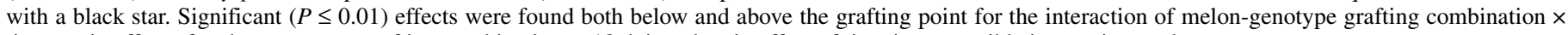
time, main effect of melon-genotype grafting combination at $18 \mathrm{dpi}$, and main effect of time in compatible interactions only. 
(Fig. 1). Race 1 was more frequent at the early phase (2 dpi) while race 1,2 was more frequent at the late time point (18 dpi). With time, race 1 reduced its presence in CHT-T/Nad-1 stems, whereas race 1,2 slightly increased. Consequently, at $18 \mathrm{dpi}$, the effect of rootstock was highly significant $(P \leq 0.01)$. Fungal colonization of the melon stem was significantly affected by the type of rootstock and by time. The incompatible combination was less colonized than the compatible one. No fungal colonies were reisolated from water inoculated plants.

Quantification of $F$. oxysporum f. sp. melonis race 1 or race 1,2 in inoculated grafted and ungrafted melon plants by qPCR. To quantify $F$. oxysporum biomass, the primer pair Fef $1 \mathrm{~F}$ (5'-TAGTCACTTTCCCTTCAATCGC-3') and Fef2R (5'-CTC AAGTGGCGGGGTAAGT-3') was specifically designed to yield a species-specific PCR product of 142 bp with no cross reaction against other Fusarium spp. or other fungal pathogens attacking melon (Fig. 2). The optimized qPCR mixture consisted of total reaction volumes of $15 \mu \mathrm{l}$ containing $6 \mu \mathrm{l}$ of total DNA $(10 \mathrm{ng} / \mu \mathrm{l})$, $7.5 \mu$ of $2 \times$ Platinum SYBR Green qPCR SuperMix-UDG (Invitrogen, Carlsbad, CA), and $0.2 \mu \mathrm{M}$ each primer. The PCR program consisted of: $50^{\circ} \mathrm{C}$ for $2 \mathrm{~min}, 95^{\circ} \mathrm{C}$ for $2 \mathrm{~min}$, and 34 cycles of $95^{\circ} \mathrm{C}$ for $15 \mathrm{~s}$ and $57^{\circ} \mathrm{C}$ for $1 \mathrm{~min}$.

The standard curve showed a linear correlation between $\mathrm{Ct}$ values and fungal DNA, with a correlation coefficient $\left(R^{2}\right)=0.999$ and an amplification efficiency of $99.9 \%$, described by the equation $y=-3.313 x+23.925$ (Fig. 3). Statistical comparison of the standard regression lines of the source of the background DNA (water versus melon stem DNA) indicated lack of significant differences between slopes and significant differences $(P<$ $0.001)$ between intercepts. Thus, a standard curve obtained by

TABLE 2. Fusarium spp. and GenBank accession numbers of translation elongation factor $1 \alpha$ gene sequences used for species-specific Fef1F/Fef2R primer pair design

\begin{tabular}{|c|c|}
\hline Species & Accession number \\
\hline Fusarium andiyazi & GU564308 \\
\hline F. andiyazi & EU620634 \\
\hline F. armeniacum & HM744692 \\
\hline F. armeniacum & GU116572 \\
\hline F. nisikadoi & AF324330 \\
\hline Gibberella circinata & AF160295 \\
\hline G. circinata & AF333930 \\
\hline F. sacchari & HM805097 \\
\hline F. sacchari & GU989189 \\
\hline F. sacchari & EF452969 \\
\hline F. sacchari & AF160278 \\
\hline F. sacchari & DQ465942 \\
\hline F. sacchari & DQ465935 \\
\hline F. sacchari & DQ465945 \\
\hline F. sacchari & GU377296 \\
\hline F. subglutinans & EU091074 \\
\hline F. subglutinans & AF160289 \\
\hline G. moniliformis & GU377299 \\
\hline F. verticillioides & FN179338 \\
\hline F. redolens & DQ854922 \\
\hline F. redolens & GU934577 \\
\hline F. redolens & HQ702586 \\
\hline F. redolens & HQ165857 \\
\hline F. redolens & FJ939707 \\
\hline F. redolens & GU250583 \\
\hline F. redolens & AF456449 \\
\hline F. redolens & AF324320 \\
\hline F. oxysporum f. sp. melonis & EF056790 \\
\hline F. oxysporum f. sp. melonis ISPaVe1018 & HE585984 \\
\hline F. oxysporum f. sp. melonis ISPaVe 1070 & HE585983 \\
\hline F. oxysporum f. sp. melonis & DQ837696 \\
\hline F. oxysporum f. sp. melonis & AF008504 \\
\hline F. oxysporum f. sp. melonis & FJ985266 \\
\hline F. oxysporum f. sp. melonis & FJ664912 \\
\hline F. oxysporum f. sp. melonis & AF363403 \\
\hline F. oxysporum & JN222908 \\
\hline F. oxysporum & DQ852627 \\
\hline
\end{tabular}

amplification of fungal DNA was normalized with the addition of melon stem DNA. The detection limit of the qPCR assay was fixed at a $F$. oxysporum DNA concentration of $1 \mathrm{pg}$ or at a $\mathrm{Ct}$ value of 34 cycles, because $F$. oxysporum DNA was not accurately quantified at a concentration of $1 \mathrm{pg}$ if fungal DNA was diluted in water or in DNA extracted from melon stem (Fig. 3).

The newly developed protocol was used to analyze the pathogen DNA amount in grafted plants-CHT-T/Nad-1 (incompatible interaction) and its reverse, Nad-1/CHT-T (compatible interaction) - and in the two ungrafted genotypes. In both combinations, both fungal races were detected along the stem at 2 dpi (Fig. 4). The amount of fungal DNA was highly affected by the type of interaction (compatible or incompatible) and time. $F$. oxysporum f. sp. melonis DNA content in grafted plants was much higher in the compatible interaction than in the incompatible one at $18 \mathrm{dpi}$. The principal significant effect $(P \leq 0.01)$ on fungal development was due to melon genotype used as rootstock, and this effect had a significant interaction with time and race. In particular, in the incompatible interaction and at the late phase (18 dpi), the amount of race 1,2 was significantly higher compared with that estimated for race 1 . Similarly, above the grafting point, the effect of the interaction fungal race $\times$ time was

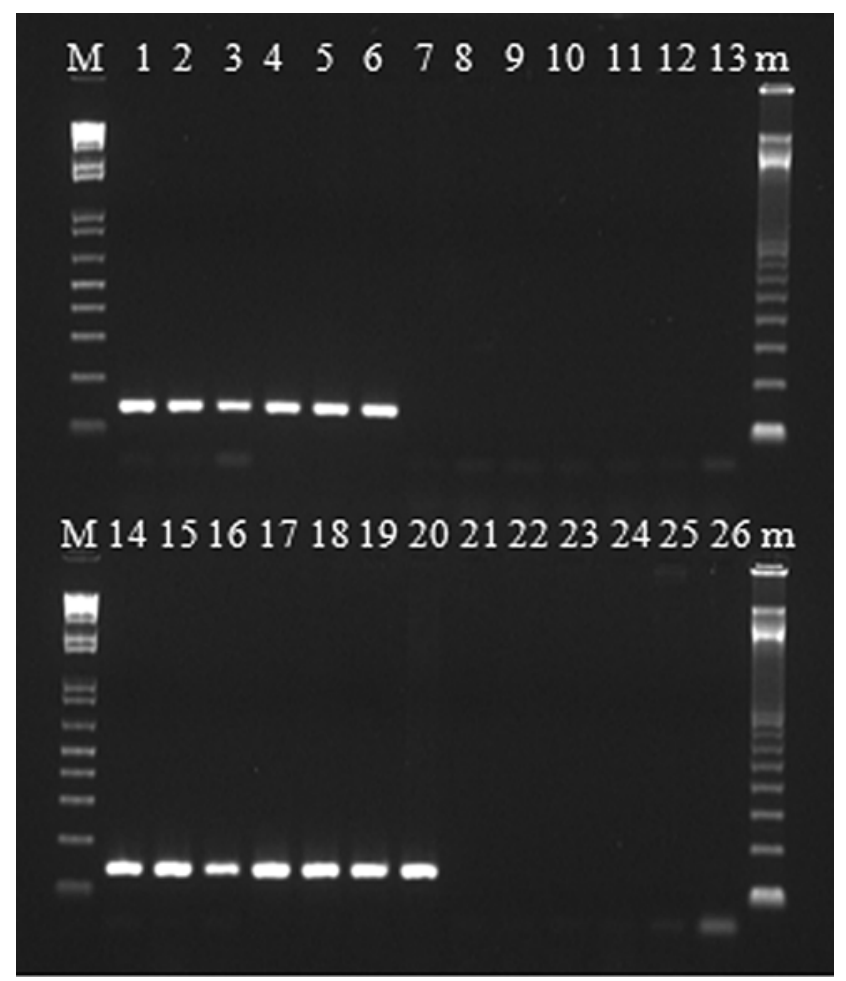

Fig. 2. Specificity of Fef1F/Fef2R primer pair tested by conventional polymerase chain reaction against several species of Fusarium and melon fungal pathogens. Lane $1, F$. oxysporum f. sp. melonis ISPaVe676; lane 2, F. oxysporum f. sp. melonis ISPaVe1069; lane 3, F. oxysporum f. sp. melonis ISPaVe1070; lane 4, F. oxysporum f. sp. melonis ISPaVe1018; lane 5, F. oxysporum f. sp. melonis ISPaVe1083; lane $6, F$. oxysporum f. sp. melonis ISPaVe2069; lane 7, F. crookwellense ISPaVe1831; lane 8, Rhizopycnis vagum ER925; lane 9, F. culmorum ISPaVe1522; lane 10, F. equiseti ISPaVe1754; lane 11, Monosporascus cannonballus ER1327; lane 12, F. lateritium ISPaVe2002; lane 13, negative control with sterile distilled water; lane 14, $F$. oxysporum f. sp. cucumerinum ISPaVe2098; lane 15, F. oxysporum f. sp. radicis-lycopersici ER1553; lane 16, F. oxysporum f. sp. radicis-cucumerinum ISPaVe2100; lane 17, $F$. oxysporum f. sp. basilici ISPaVe2097; lane 18, F. oxysporum f. sp. lycopersici ISPaVe2102; lane 19, F. oxysporum ISPaVe18; lane $20, F$. oxysporum ISPaVe904; lane $21, F$. poae ISPaVe1704; lane 22, F. redolens ER1276; lane 23, Pyrenochaeta lycopersici ER1278; lane 24, F. solani f. sp. cucurbitae ISPaVe931; lane 25, Acremonium cucurbitacearum ER1517; lane 26, Plectosporium tabacinum ISPaVe835; lane M, 1-kb-plus ladder marker (Invitrogen); and lane m, 100-bp ladder marker (New England BioLabs). 
also significant (Fig. 4). Tukey's multiple range test $(P \leq 0.01)$ performed on the theses analyzed at both time points (AV2 statistical analysis) indicated that the amount of fungal DNA in the ungrafted CHT-T (0.041 ng below and $0.08 \mathrm{ng}$ above 40 to $45 \mathrm{~mm}$ ) was significantly higher than in Nad-1/CHT-T $(0.0080 \mathrm{ng}$ below and $0.0091 \mathrm{ng}$ above the grafting point); and, in Nad1/CHT-T (compatible interaction), it was significantly higher compared with that estimated in the incompatible interaction CHT-T/Nad-1 (0.000099 ng below and $0.00017 \mathrm{ng}$ above the grafting point). Accordingly, when comparing data obtained exclusively at the $18 \mathrm{dpi}$ (AV1 statistical analysis), the amount of fungal DNA in CHT-T/Nad-1 $(0.000138 \mathrm{ng}$ below and 0.000279 ng above the grafting point) was significantly lower than in Nad-1 ( $0.005806 \mathrm{ng}$ below and $0.016573 \mathrm{ng}$ above 40 to $45 \mathrm{~mm}$ ) as well as in Nad-1/CHT-T $(0.015823 \mathrm{ng}$ below and 0.018087 above the grafting point), either below or above the grafting point.

The use of the qPCR protocol allowed the detection of $F$. oxysporum $\mathrm{f}$. sp. melonis DNA in $100 \%$ of stem sections of the two melon genotypes regardless of resistance or susceptibility. No Fef1F/Fef2R amplification was obtained from water-inoculated plant samples.

As a general observation, the colonization of both $F$. oxysporum f. sp. melonis races was strongly inhibited in the incompatible interaction with CHT-T/Nad-1, thus confirming the dominance of the rootstock on the whole-plant response. Moreover, data showed that the simple presence of the resistant genotype, even when used as scion (Nad-1/CHT-T), decreased fungal development compared with CHT-T seedlings (Fig. 4).

\section{DISCUSSION}

The aim of this work was to develop a tool enabling the detection and quantification of $F$. oxysporum in plant tissue which was applied to the quantification of $F$. oxysporum $\mathrm{f}$. sp. melonis in compatible and incompatible interactions with grafted and un- grafted melon genotypes. We fulfilled the objectives, and the newly developed primers pair was highly specific to $F$. oxysporum without cross reactions with other Fusarium spp. and the common melon fungal pathogens. The protocol was highly sensitive and detected $F$. oxysporum in asymptomatic melon stems at the early infection stage, with a quantification limit of $1 \mathrm{pg}$ of fungal DNA. Similar detection limits were found in other qPCR protocols for the detection of vascular-infecting fungi, including Fusarium spp. or other formae speciales of $F$. oxysporum in planta and soil $(11,17,18,20,29,39)$. In the referenced protocols, the target sequence of the qPCR was within the ribosomal DNA that occurs in multiple copies, or the primers were developed on a SCARspecific target sequence. Instead, we used the TEF- $1 \alpha$ gene for our primer design. This gene, which occurs as a single copy within the genome, is extensively used in Fusarium spp. phylogeny, because it is highly informative at the species level $(13,27)$. The newly developed primer set, Fef1F and Fef2R, unambiguously differentiated $F$. oxysporum from other Fusarium spp., generating an amplicon shorter than $200 \mathrm{bp}$, which allows an efficient, reliable, and repeatable qPCR.

The use of this protocol allowed us to clearly detect $F$. oxysporum. Thereafter, colonies obtained from reisolations were confirmed as $F$. oxysporum f. sp. melonis race 1 or race 1,2 because they were reinoculated on CHT-T and Charentais-Fom2, respectively, for further investigations (data not shown). Moreover, no contaminations were obtained from water-inoculated melon plants used as controls, confirming that no other Fusarium spp. or F. oxysporum were present than the strains used as inoculum.

qPCR detected and quantified the amount of pathogen DNA in stem tissues at $2 \mathrm{dpi}$, when plants showed no or scarcely discernible symptoms. Because the limitation of a qPCR protocol, shared by all molecular detection and quantification methods, is the inability to distinguish viable from not viable fungal material, isolations from host tissue were performed, and the results supported differences in colonization profiles between $F$. oxysporum

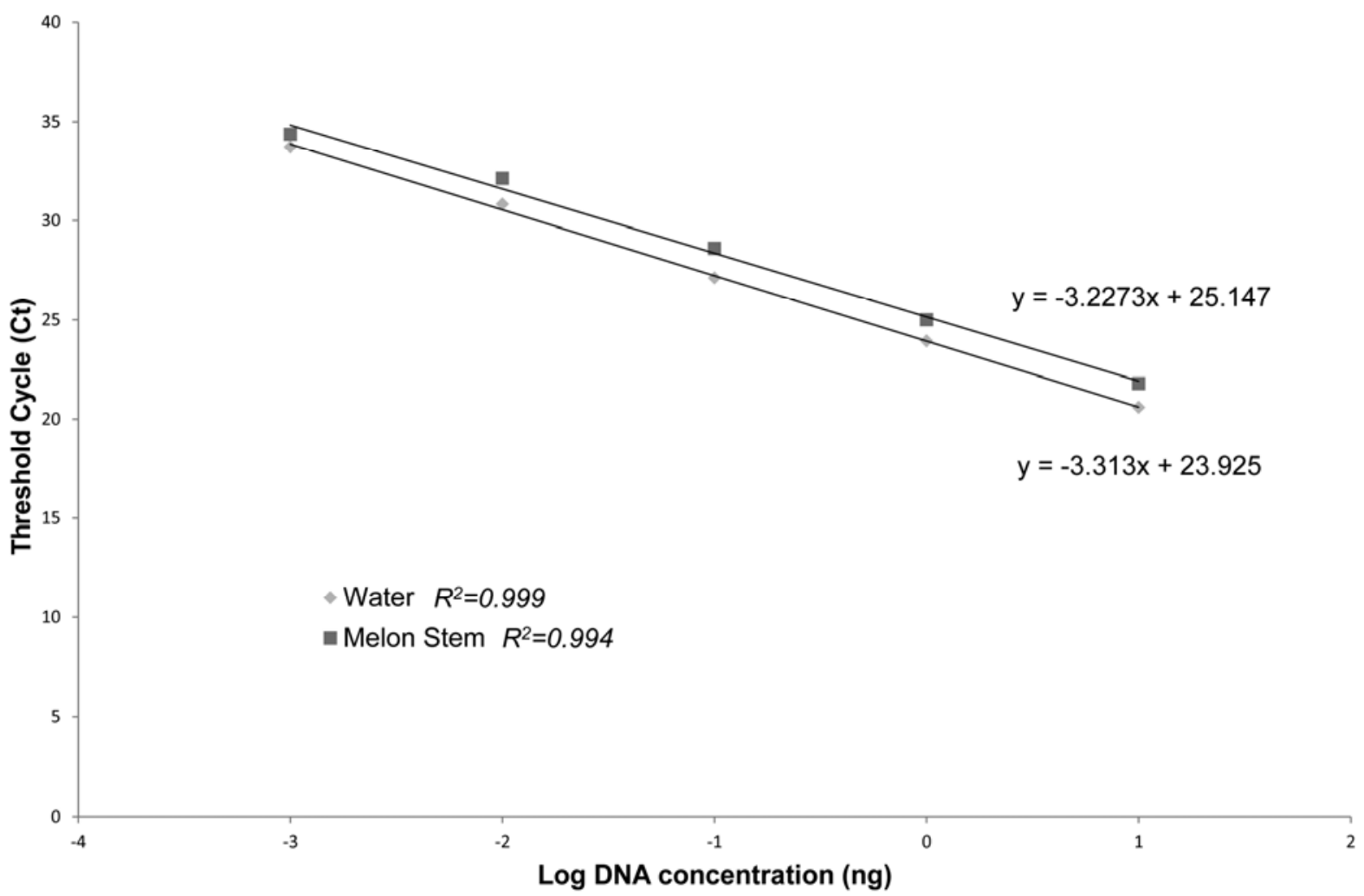

Fig. 3. Standard regression lines of a five-point 10-fold serial dilution of Fusarium oxysporum f. sp. melonis (ISPaVe1018) DNA (10 ng/ $\mu$ l) diluted in sterile, ultrapure water (water series) or in DNA (50 ng) extracted from melon stems. Threshold cycles (Ct) were plotted against the log of genomic DNA standard curves of known concentrations. 
f. sp. melonis races obtained by qPCR. Nevertheless, the DNA of both fungal races was assessed by qPCR at the early time point ( 2 dpi) above the grafting point, where a minimal fungal presence was revealed by reisolations in either the compatible or incompatible interaction, confirming the higher sensitivity of the qPCR methodology. The present study also provides new information on the effects of grafting. Though grafting is a widely applied system in commercial melon cultivation $(3,5)$, knowledge is lacking on interactions between scion and rootstock genotypes and on their effects on the vascular pathogen colonization. On this account, we investigated both grafted and ungrafted plants of CHT-T (susceptible) and Nad-1 (resistant). To our knowledge, this is the first study carried out to both detect and quantify fungal infection in grafted plants by means of real-time PCR.

In grafted plants, the response to the pathogen is affected by rootstock characteristics (i.e., the resistant rootstock Nad-1 makes the whole plant asymptomatic), which is the practical reason for the commercial use of resistant rootstocks. The general hypothe-

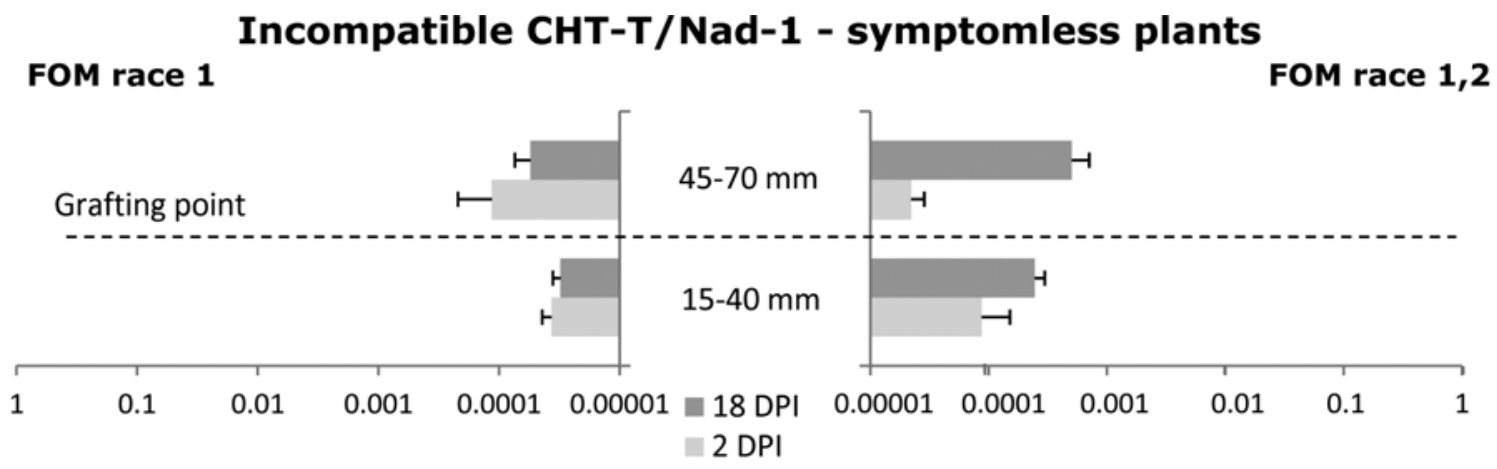

FOM race 1

Nad-1 - symptomless plants

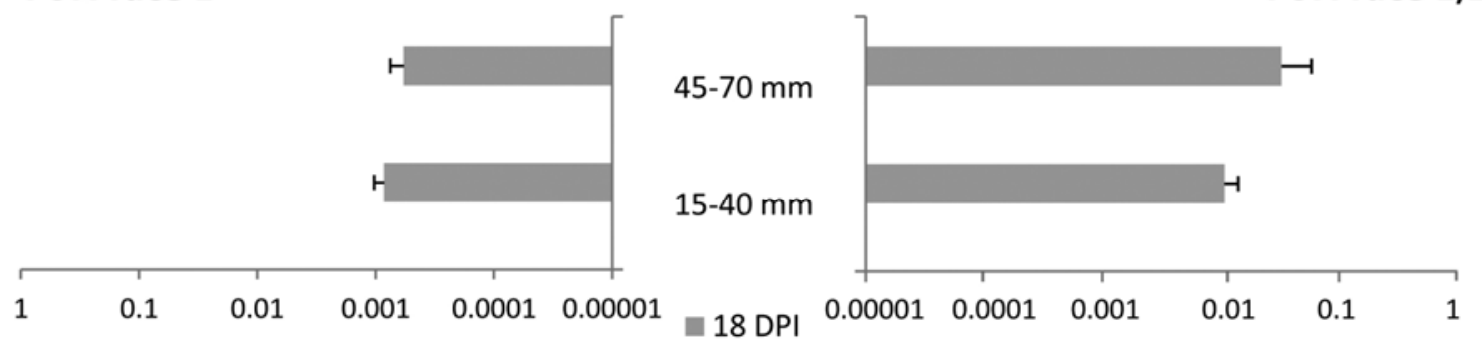

FOM race 1,2

FOM race 1

Compatible Nad-1/CHT-T - symptomatic plants

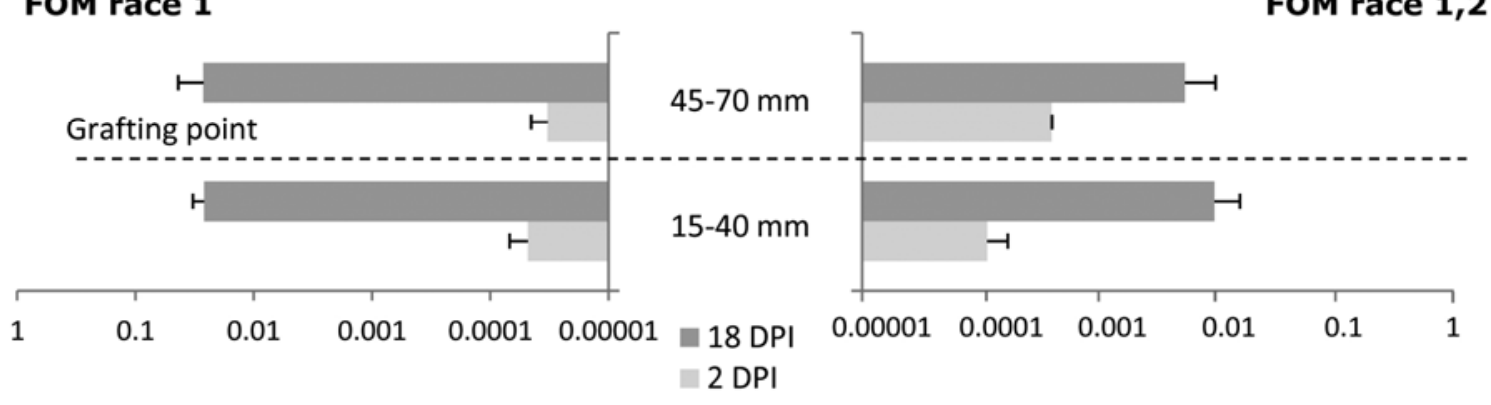

FOM race 1

\section{Charentais-T - symptomatic plants}

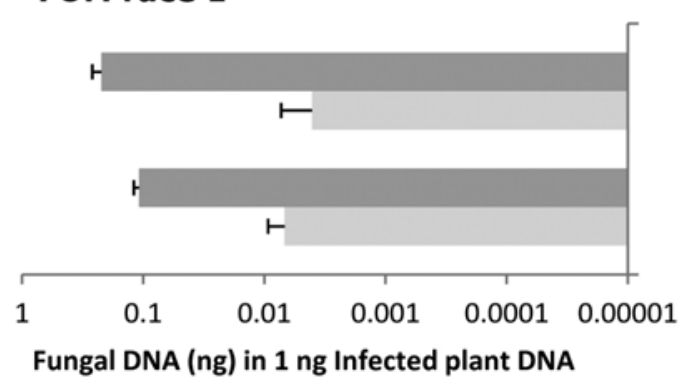

FOM race 1,2

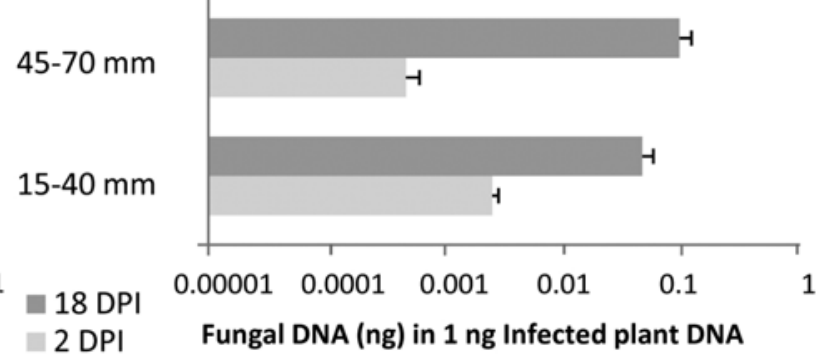

Fig. 4. Amounts of Fusarium oxysporum f. sp. melonis DNA assessed by quantitative polymerase chain reaction (fungal DNA [ng] present in 1 ng of DNA extracted from infected plants) using Fef1F/Fef2R primer pair in infected grafted melon plants ('Charentais-T' [CHT-T]/'Nad-1'] (incompatible interaction) or Nad-1/CHT-T (compatible interaction) or in ungrafted plants (Nad-1 resistant and CHT-T susceptible). Data are shown in $\log _{10}$ scale. Graphs indicate mean values \pm standard error of the mean. Significant effects $(P \leq 0.01)$ were found both below and above the grafting point for melon-genotype grafting combination, time, fungal race $\times$ melon-genotype grafting combination, or time $\times$ melon-genotype grafting combination. Above the grafting point, the effect of the fungal race $\times$ time interaction was also significant $(P \leq 0.01)$. 
sis underlying this use is that the rootstock genotype constitutes a physical or biochemical barrier against the fungus that infects through roots; consequently, the pathogen cannot reach the susceptible scion or is drastically impeded (3). This general assumption has been partially supported by the present study. As a matter of fact, the biomass of both races was drastically reduced in the incompatible interaction; however, the pathogen was detected also in the scion with either reisolations or qPCR. As expected, both incompatible interactions, CHT-T/Nad-1 and Nad1 , remained completely symptomless. The influence of the resistant genotype also is detectable when it is used as a scion (i.e., Nad-1/CHT-T compatible interaction), inducing a significant reduction of fungal development compared with that assessed in CHT-T ungrafted plants. This result gives further support to the effect of the scion on the response of grafted plants and to the general indication that the resistance level achieved by grafting also depends on the scion (3).

Considering the differences between the two $F$. oxysporum $\mathrm{f}$. sp. melonis races, race 1 was generally faster in colonizing the melon plant than race 1,2 , but its presence and quantity was reduced with time in incompatible interactions (CHT-T/Nad-1) $(2,37)$. This could be due to the absence of a stable or continuous colonization at the early stage of infection ( $2 \mathrm{dpi}$ ), so that the presence or quantity of race 1 decreases with time in the incompatible interaction. These results support the observations already reported by reisolations (37) or by a GFP-expressing strain (40). Conversely, race 1,2 affirms its presence at the late time point in the incompatible interactions. In fact, this race produced the highest amount of biomass assessed in the incompatible interaction (CHT-T/Nad-1 or in Nad-1 ungrafted plants) at 18 dpi (Fig. 4). The ability of race 1,2 to grow in resistant melon genotypes, without inducing symptoms, has already been reported by using a GFP-expressing strain $(6,16,40)$.

Quantitative assessments obtained by the use of this newly developed protocol complete the descriptive picture obtained with GFP markers of the xylem colonization already reported for $F$. oxysporum $(6,16,40)$. The GFP studies reported that the fungus colonized the plant and invaded xylem vessels, being essentially confined within them. Furthermore, F. oxysporum f. sp. melonis race 1,2 is able to invade resistant plants, although to a lesser extent than susceptible ones (40), thus supporting our results.

This study shows that, even in the incompatible melon genotype, both races are present but, in grafted plants, the maximum quantity reached by the pathogen is significantly lower than in the ungrafted plants. In any case, the resistant genotype (Nad-1) has an evident influence on both fungal races by reducing their development.

In all experiments, race 1,2 (ISPaVe1018) has the highest ability to grow in melon stems in the presence of host resistance. Interestingly, race 1,2 grew $>0.05 \mathrm{ng} / \mathrm{ng}$ of plant DNA without inducing symptoms in the resistant Nad-1 ungrafted genotype whereas, in the compatible interaction, a lower amount of the fungus incited wilting symptoms. Therefore, it seems evident that, in the F. oxysporum f. sp. melonis-melon combination, the ability of $F$. oxysporum to colonize the plant is independent from the ability to induce symptoms.

The rapid and reliable detection of pathogens, particularly soilborne, are important features in formulating strategies for disease management in either plant nurseries or open fields (23). The qPCR system is less time consuming then isolations and has higher sensitivity due to the ability to detect $F$. oxysporum f. sp. melonis in melon stems where no growth was found by culturing. The qPCR protocol might have direct applications in studies on microbial ecology and plant pathology, because it provides opportunities for analyzing $F$. oxysporum populations and their interactions with the host.

The different behavior observed between $F$. oxysporum f. sp. melonis race 1 and 1,2, in colonizing melon plants suggests a different genetic background as a probable result of independent evolutionary processes $(12,24,32)$. Further work will be performed to study this different genetic background by comparative genomic analyses, which might provide novel models of molecular diversification and genetic transmission to explain how fungal genomes adapt to pathogenic behavior.

\section{ACKNOWLEDGMENTS}

The study was financially supported by the RESPAT project granted by Consiglio per la ricerca e la sperimentazione in agricoltura of Italy. We thank A. Chandelier, L. Cattivelli, M. Aragona, S. De Felice, and A. Polverari for their helpful suggestions.

\section{LITERATURE CITED}

1. Anderson, M. J., and Ter Braak, C. 2003. Permutation tests for multifactorial analysis of variance. J. Stat. Comput. Simul. 73:85-113.

2. Catalano, V., Haegi, A., Luongo, L., Ficcadenti, N., and Belisario, A. 2010. Differential colonization of resistant and susceptible melon genotypes infected by Fusarium oxysporum f. sp. melonis. J. Plant Pathol. 92:78.

3. Cohen, R., Horev, C., Burger, Y., Shriber, S., Hershenhorn, J., Katan, J., and Edelstein, M. 2002. Horticultural and pathological aspects of Fusarium wilt management using grafted melons. HortScience 37:10691073.

4. Conover, W. J., and Iman, R. L. 1981. Rank transformations as a bridge between parametric and nonparametric statistics. Am. Stat. 35:124-129.

5. Crinò, P., lo Bianco, C., Rouphael, Y., Colla, G., Saccardo, F., and Paratore, A. 2007. Evaluation of rootstock resistance to Fusarium wilt and gummy stem blight and effect on yield and quality of a grafted 'Inodorus' melon. HortScience 42:521-525.

6. Di Pietro, A., Madrid, M. P., Caracuel, Z., Delgado-Jarana, J., and Roncero, M. I. G. 2003. Fusarium oxysporum: exploring the molecular arsenal of a vascular wilt fungus. Mol. Plant Pathol. 4:315-325.

7. Edel, V., Aim, S., Cordier, C., Olivain, C., Steinberg, C., and Alabouvette, C. 2011. Development of a strain-specific real-time PCR assay for the detection and quantification of the biological control agent Fo47 in root tissues. FEMS Microbiol. Lett. 322:34-40.

8. Edel, V., Steinberg, C., Gautheron, N., and Alabouvette, C. 2000. Ribosomal DNA-targeted oligonucleotide probe and PCR assay specific for Fusarium oxysporum. Mycol. Res. 104:518-526.

9. Edgington, E. S., and Onghena, P. 2007. Randomization Tests, Fourth ed. Chapman and Hall/CRC Press, Boca Raton, FL.

10. Ficcadenti, N., Sestili, S., Annibali, S., Campanelli, G., Belisario, A., Maccaroni, M., and Corazza, L. 2002. Resistance to Fusarium oxysporum f. sp. melonis race 1,2 in muskmelon lines Nad-1 and Nad-2. Plant Dis. 86:897-900.

11. Filion, M., St. Arnaud, M., and Jabaji-Hare, S. H. 2003. Quantification of Fusarium solani f. sp. phaseoli in mycorrhizal bean plants and surrounding mycorrhizosphere soil using real-time polymerase chain reaction and direct isolations on selective media. Phytopathology 93:229235.

12. Fourie, G., Steenkamp, E. T., Ploetz, R. C., Gordon, T. R., and Viljoen, A. 2011. Current status of the taxonomic position of Fusarium oxysporum formae specialis cubense within the Fusarium oxysporum complex. Infect. Genet. Evol. 11:533-542.

13. Geiser, D. M., Jiménez-Gasco, M. M., Kang, S., Makalowska, I., Veeraraghavan, N., Ward, T. J., Zhang, N., Kuldau, G. A, and O'Donnell, K. 2004. FUSARIUM-ID v. 1.0: A DNA sequence database for identifying Fusarium. Eur. J. Plant Pathol. 110:473-479.

14. Gordon, T. R., and Martyn, R. D. 1997. The evolutionary biology of Fusarium oxysporum. Annu. Rev Phytopathol. 35:11-128.

15. Gordon, T. R., Okamoto, D., and Jacobson, D. J. 1989. Colonization of muskmelon and non susceptible crops by Fusarium oxysporum f. sp. melonis and other species of Fusarium. Phytopathology 79:1095-1100.

16. Inoue, I., Namiki, F., and Tsuge, T. 2002. Plant colonization by vascular wilt fungus Fusarium oxysporum requires FOW1, a gene encoding a mitochondrial protein. Plant Cell 14:1869-1883

17. Jimenez-Fernandez, D., Montes-Borrego, M., Jiménez-Díaz, R. M., Navas-Cortés, J. A., and Landa, B. B. 2011. In planta and soil quantification of Fusarium oxysporum f. sp. ciceris and evaluation of Fusarium wilt resistance in chickpea with a newly developed quantitative polymerase chain reaction assay. Phytopathology 101:250-262.

18. Jimenez-Fernandez, D., Montes-Borrego, M., Navas-Cortés, J. A., Jiménez-Díaz, R. M., and Landa, B. B. 2010. Identification and quantification of Fusarium oxysporum in planta and soil by means of an improved specific and quantitative PCR assay. Appl. Soil Ecol. 46:372-382. 
19. Lievens, B., Brouwer, M., Vanachter, A. C. R. C., Cammue, B. P. A., and Thomma, B. P. H. J. 2006. Real-time PCR for detection and quantification of fungal and oomycete tomato pathogens in plant and soil samples. Plant Sci. 171:155-165.

20. Lievens, B., Claes, L., Vakalounakis, D. J., Vanachter, A. C. R. C., and Thomma, B. P. H. J. 2007. A robust identification and detection assay to discriminate the cucumber pathogens Fusarium oxysporum f. sp. cucumerinum and f. sp. radicis-cucumerinum. Environ. Microbiol. 9:21452161.

21. Lievens, B., Rep, M., and Thomma, B. 2008. Recent developments in the molecular discrimination of formae speciales of Fusarium oxysporum. Pest Manage. Sci. Online publication. doi: $10.1002 / \mathrm{ps}$

22. Lievens, B., van Baarlen, P., Verreth, C., van Kerckhove, S., Rep, M., and Thomma, B. 2009. Evolutionary relationships between Fusarium oxysporum f. sp. lycopersici and $F$. oxysporum f. sp. radicis-lycopersici isolates inferred from mating type, elongation factor-1a and exopolygalacturonase sequences. Mycol. Res. 113:1181-1191.

23. Lopez-Mondejar, R., Beaulieu, R., Ros, M., and Pascual, J. A. 2012. SCAR-based real-time TaqMan PCR for early detection of Fusarium oxysporum in melon seedlings under greenhouse nursery conditions. Crop Prot. 33:1-6.

24. Ma, L. J., van der Does, H. C., Borkovich, K. A., Coleman, J. J., Daboussi, M.-J., Di Pietro, A., Dufresne, M., Freitag, M., Grabherr, M., Henrissat, B., Houterman, P. M., Kang, S., Shim, W.-B., Woloshuk, C., Xie, X., Xu, J.-R., Antoniw, J., Baker, S. E., Bluhm, B. H., Breakspear, A., Brown, D. W., Butchko, R. A. E., Chapman, S., Coulson, R., Coutinho, P. M. Danchin, E. G. J., Diener, A., Gale, L. R., Gardiner, D. M., Goff, S., Hammond-Kosack, K. E., Hilburn, K., Hua-Van, A., Jonkers, W., Kazan, K., Kodira, C. D., Koehrsen, M., Kumar, L., Lee, Y.-H., Li, L., Manners, J. M., Miranda-Saavedra, D., Mukherjee, M., Park, G., Park, J., Park, S.-Y., Proctor, R. H., Regev, A., Ruiz-Roldan, M. C., Sain, D., Sakthikumar, S., Sykes, S., Schwartz, D. C., Turgeon, B. G., Wapinski, I., Yoder, O., Young, S., Zeng, Q., Zhou, S., Galagan, J., Cuomo, C. A., Kistler, H. C., and Rep, M. 2010. Comparative genomics reveals mobile pathogenicity chromosomes in Fusarium. Nature 464:367-373.

25. Michielse, C. B., and Rep, M. 2009. Pathogen profile update: Fusarium oxysporum. Mol. Plant Pathol. 10:311-324.

26. Mishra, P. K., Fox, R. T. V., and Culham, A. 2003. Development of a PCR-based assay for rapid and reliable identification of pathogenic Fusaria. FEMS Microbiol. Lett. 218:329-332.

27. O’Donnell, K., Gueidan, C., Sink, S., Johnston, P. R., Crous, P. W., Glenn, A., Riley, R., Zitomer, N. C., Colyer, P., Waalwijk, C., van der Lee, T., Moretti, A., Kang, S., Kim, H. S., Geiser, D. M., Juba, J. H., Baayen, R. P., Cromey, M. G., Bithel, S., Sutton, D. A., Skovgaard, K., Ploetz, R., Kistler, H. C., Elliott, M., Davis, M., and Sarver, B. A. J. 2009. A two- locus DNA sequence database for typing plant and human pathogens within the Fusarium oxysporum species complex. Fungal Genet. Biol. 46:936-948

28. O’Donnell, K., Kistler, H. C., Cigelnik, E., and Ploetz, R. C. 1998. Multiple evolutionary origin of the fungus causing Panama disease of banana; Concordant evidence from nuclear and mitochondrial gene genealogies. Proc. Natl. Acad. Sci. USA 95:2044-2049.

29. Pasquali, M., Piatti, P., Gullino, M. L., and Garibaldi, A. 2006. Development of a real-time polymerase chain reaction for the detection of Fusarium oxysporum f. sp. basilici from basil seed and roots. J. Phytopathol. 154:632-636.

30. Perchepied, L., and Pitrat, M. 2004. Polygenic inheritance of partial resistance to Fusarium oxysporum f. sp. melonis race 1,2 in melon. Phytopathology 94:1331-1336.

31. Pillar De Patta, V. 2006. MULTIV. Multivariate Exploratory Analysis, Randomization Testing and Bootstrap Resampling. User's Guide v. 2.4. Universidade Federal do Rio Grande do Sul, Porto Alegre, Brazil.

32. Rep, M., and Kistler, H. C. 2010 The genomic organization of plant pathogenicity in Fusarium species. Curr. Opin. Plant Biol. 13:420-426.

33. Risser, G., Banihashemi, Z., and Davis, D. W. 1976. A proposed nomenclature of Fusarium oxysporum f. sp. melonis races and resistance genes in Cucumis melo. Phytopathology 66:1105-1106.

34. Sakata, Y., Ohara, T., and Sugiyama, M. 2008. The history of melon and cucumber grafting in Japan. Acta Hortic. 767:217-228.

35. SAS. 1985. Users Guide: Statistics. SAS Institute, Cary, NC.

36. Schena, L., Nigro, F., Ippolito, A., and Gallitelli, D. 2004. Real-time quantitative PCR: A new technology to detect and study phytopathogenic and antagonistic fungi. Eur. J. Plant Pathol. 110:893-908.

37. Sestili, S., Polverari, A., Luongo, L., Ferrarini, A., Scotton, M., Hussain, J., Delledonne, M., Ficcadenti, N., and Belisario, A. 2011. Distinct colonization patterns and cDNA-AFLP transcriptome profiles in compatible and incompatible interactions between melon and different races of Fusarium oxysporum f. sp. melonis. BMC Genomics 12:122. Online publication. doi:10.1186/1471-2164-12-122

38. Thompson, J. D., Gibson, T. J., Plewniak, F., Jeanmougin, F., and Higgins, D. G. 1997. The CLUSTAL_X windows interface: Flexible strategies for multiple sequence alignment aided by quality analysis tools. Nucleic Acids Res. 25:4876-4882.

39. Zhang, Z., Zhang, J., Wang, Y., and Zheng, X. 2005. Molecular detection of Fusarium oxysporum f. sp. niveum and Mycosphaerella melonis in infected Plant tissues and soils. FEMS Microbiol. Lett. 249:39-46.

40. Zvirin, T., Herman, R., Brotman, Y., Denisov, Y., Belausov, E., Freeman, S., and Perl-Treves, R. 2010. Differential colonization and defence responses of resistant and susceptible melon lines infected by Fusarium oxysporum race 1-2. Plant Pathol. 59:576-585. 